\title{
Financial Performance Measurement of a Commercial Bank: A Case of Bank of China Hongkong
}

\author{
Jeyaraj, S. S. ${ }^{1 *}$, Sumathi, M. ${ }^{2}$ \\ ${ }^{1}$ Sino-British College (Partnership Program with Staffordshire University, UK), Guangxi University for \\ Nationalities, Guangxi Province, China \\ 2 PG \& Research Department of Commerce, NMSS Vellaichamy Nadar College, Madurai District, Tamilnadu \\ State, India
}

\begin{abstract}
This study focuses on measuring the financial performance of Bank of China's profitability, solvency, and liquidity using secondary data for the period from 2008 to 2017. Various techniques such as horizontal, vertical, and ratio analysis are employed to measure financial performance. Statistical tools such as mean, standard deviation, and co-efficiency of variation measure financial data to emphasize the comparative and relative importance of presentation. The study reveals that BOC's horizontal and vertical analysis indicates a variable growth rate of percentage and amount of $\mathrm{HK} \$$ due to external and internal operating environmental factors. Ratio analysis reveals that the BOC was conducted in a rational and normal way except 2008, 2012, 2013, and 2015 due to the Lehman brothers' mini-bond issue, Global financial crisis, Backdrop of shrinking international trade, extreme movements in commodity prices (oil prices) and frequent swings in financial markets. Based on the findings, BOC formulates the policies to overcome the factors that would help the investors identify the banking sector's nature and assist in making their investment.
\end{abstract}

Keywords: Horizontal Analysis, Financial Ratios, Liquidity, Financial Performance, Profitability, Solvency, Vertical Analysis, Financial Crisis

JEL Classification: F31, G170, G32, G33, G010, G30, G21, G23

Paper Type: Review

* Corresponding author: E-mail: jeyarajphd@gmail.com, 


\section{INTRODUCTION}

The growth and development of the modern economy depend on the banking sector. The banking sector business is essential for a country's economic development. Its financing requirements of trade, industry and agriculture are met with a higher degree of commitment and responsibility. According to Jain and Jaiswal (2016), the banking sector is the country's backbone. It is one of the financial sector's critical financial supports, which plays an active role in its functioning. Funso, Kolade, and Ojo (2012) cited in their study that financial sectors play a crucial role in economic growth and industrialization by channelling funds from surplus units the depositors to the deficit units, the borrowers process gaining from the spread of the separate interest charged. Their intermediation role can be said to be a catalyst for economic growth. The development of the banking industry is a good reflection of the development of the economy. It is noticeable that a country's economic condition depends on these decisions' speed; hence, the faster these are made, the faster the economy would improve. The banking sector's performance is perceived as the replica of economic activities of the economy. Measurement of the banking sector's financial performance is an effective measure and indicator to check a nation's economic activities' soundness. Hence, the development of a country is linked with the development of the banking sector integrally.

In a modern economy, banks are considered traders in money and as the leaders of development. The role and importance of banks of a modern economy are enormous (Bikker, 2010; Rashid, 2010; Altan, Beduk \& Yusufazari, 2014) and its services which it provides growing in terms of depth, the number of institutions, and the amount of money managed by such institutions. Banks play an essential role in distributing deposits and disbursement of credit to various economic sectors and individuals. An economy's strength depends on the financial system's strength and efficiency, which depends on a sound and solvent banking system. A sound banking system efficiently mobilized savings in productive sectors. A solvent banking system ensures that the bank can meet its obligation to the depositors.

Financial statement analysis highlights an essential relationship in the financial statement. It embraces the method issued in assessing and interpreting past performance and current financial position related to specific interest factors in investment decisions by Jawahar Lal (2003a). Financial statement analysis requires internal and external users to identify trends by comparing ratios through different types of statements and periods, analyzing a company's financial statements for decision-making purposes through profitability, liquidity, and activity ratios. The financial statement analysis evaluates the relationship between parts of financial statements to understand better its position and performance (Metcalf \& Titard, 1976). According to Narayanaswamy (2014), the primary purpose of financial statement analysis is to utilize information about its past performance to predict how it will fare in the future. Khan and Jain (2007a) stated in Management Accounting that financial performance is the process of selecting, relation, and evaluating the financial performance's focus on the financial statement's financial statement and significant relationship between them. The financial statement analysis evaluates the relationship between parts of a financial statement to understand its position and performance.

Moreover, financial performance analysis is the best procedure for significantly analyzing a bank's financial characteristics from financial statements. Such analysis aims to determine the bank's management's efficiency and performance, as reflected in the report. Yalcin, Bayrakdarogly, and Kahraman (2012) pointed out that financial performance has 
a broad concept, including economic growth, return, and productivity; using the financial ratios in the performance assessment can be appropriate for companies and other counterparts. Rees (1995) stated that financial ratio analysis responds to the amounts of information held in the financial statements and compares firms with different sizes. Using them, both analysts and investors would summarize and analyze related quantitative information to obtain momentous data to appraise the firm's operation, investigate its situation in the sector, and make financial decisions (Singh \& Schmidgall, 2002). Beaver (2002) specified that forecasting the companies' performance affects the speed of making capital market investment decisions. Hence, the present study investigates the Bank of China's financial statements, Hong Kong, and measures financial performance from 2008 to 2017 through horizontal, vertical, and ratio analysis.

\section{LITERATURE REVIEW}

A literature review is usually conducted to review the present status of a particular research topic which is collected through dissertations, published and unpublished theses, research reports, case studies; review reports, conference papers, chapter schemes, articles from national and international journals, books from the printed and online version and other materials. It assists the researcher in developing a more robust understanding of the theoretical implications of the proposed inquiry. The present study has certain limitations due to published financial data, so it is subject to all integral limitations in the condensed published financial statements-the subsequent studies related to the measurement of financial performance.

\section{OBJECTIVES OF THE STUDY}

Generally speaking, the objectives of the measures are to apprehend the information contained in financial statements to know the weaknesses and strengths of the firm and to make a forecast about the prospects of the firm thereby, enabling the analysts to make decisions regarding the operation of, and further investment in, the firm (Khan \& Jain, 2007b). The specific objectives of BOCs financial performance are:

(a) To examine the financial performance of the bank under various components of horizontal, vertical, and ratio analysis;

(b) To investigate the overall financial performance of the bank over a given period from 2008 to 2017; and

(c) To identify the factors which are associated with the financial performance of the bank.

\section{HYPOTHESIS OF THE STUDY}

The present study addresses the following hypotheses:

$\mathrm{H} 1$ : Methods of financial statement analysis related to the financial performance of the Bank of China.

H2: Global environmental factors are associated with the Bank of China's financial performance from 2008 to 2017.

H3: There is a significant statistical relationship between financial ratios analysis and the Bank of China's Performance's power and weakness. 
Table 1. Summary of Literature on Financial Performance of Commercial Banks

\begin{tabular}{|c|c|c|c|c|c|c|}
\hline $\mathrm{S} / \mathrm{N}$ & Study & Purpose & $\begin{array}{l}\text { Year } \\
\text { Covered }\end{array}$ & $\begin{array}{l}\text { Estimation } \\
\text { Method }\end{array}$ & Variable & Summary of Findings \\
\hline 1 & $\begin{array}{l}\text { Khan Samad } \\
(2004 a)\end{array}$ & $\begin{array}{l}\text { Performance of Bahrain's } \\
\text { commercial banks with } \\
\text { respect to credit, liquidity, } \\
\text { and profitability } \\
\text { performances }\end{array}$ & $\begin{array}{l}1994 \text { - } \\
2001\end{array}$ & T-test & $\begin{array}{l}\text { Ten Financial ratios } \\
\text { measuring credit, } \\
\text { liquidity, and } \\
\text { profitability }\end{array}$ & $\begin{array}{l}\text { Commercial banks' liquidity performance is not at } \\
\text { par with the banking industry. Commercial banks } \\
\text { are relatively less profitable and less liquid and } \\
\text { are exposed to risk compared to the banking } \\
\text { industry. }\end{array}$ \\
\hline 2 & $\begin{array}{l}\text { Bashir } \\
(1999)\end{array}$ & $\begin{array}{l}\text { Determinants, the } \\
\text { relationship between the } \\
\text { profitability and the Islamic } \\
\text { bank performance }\end{array}$ & $\begin{array}{l}1993- \\
1998\end{array}$ & $\begin{array}{l}\text { Linear } \\
\text { Equation, } \\
\text { Regression } \\
\text { Analysis }\end{array}$ & $\begin{array}{l}\text { Non-interest earning } \\
\text { assets and customer } \\
\text { and short-term } \\
\text { financing }\end{array}$ & $\begin{array}{l}\text { The study concluded that foreign-owned banks } \\
\text { are more profitable than their domestic } \\
\text { counterparts. Furthermore, favourable } \\
\text { macroeconomic conditions impact performance } \\
\text { measures positively, and results also show that } \\
\text { stock markets are complementary to bank } \\
\text { financing. }\end{array}$ \\
\hline 3 & $\begin{array}{l}\text { Saroja L. } \\
\text { and Srinivas } \\
\text { K. (2013) }\end{array}$ & $\begin{array}{l}\text { Comparative Financial } \\
\text { Performance of HDFC } \\
\text { Bank and ICICI Bank }\end{array}$ & $\begin{array}{l}2003- \\
2012\end{array}$ & $\begin{array}{l}\text { CAMELS } \\
\text { model with t- } \\
\text { test }\end{array}$ & $\begin{array}{l}\text { The net profit, } \\
\text { operating profit, return } \\
\text { on net-worth, spread, } \\
\text { liquidity, and loans to } \\
\text { the total assets of the } \\
\text { HDFC bank have } \\
\text { more than ICICI bank. }\end{array}$ & $\begin{array}{l}\text { The total advances to customer deposit, debt- } \\
\text { equity, and burden of HDFC have less than ICICI } \\
\text { bank. Hence, long-term solvency is well in ICICI } \\
\text { bank. The CAMELS' analysis and t-test } \\
\text { concludes that there is no significant difference } \\
\text { between the ICICI and HDFC bank's financial } \\
\text { performance, but the ICICI bank performance is } \\
\text { slightly less compared with HDFC }\end{array}$ \\
\hline 4 & $\begin{array}{l}\text { Alsamaree, } \\
\text { Adnan } \\
\text { Hashim } \\
(2013)\end{array}$ & $\begin{array}{l}\text { A study on the financial } \\
\text { performance of commercial } \\
\text { banks in particular during } \\
\text { the critical period from } \\
2007 \text { to } 2010\end{array}$ & $\begin{array}{l}2007- \\
2010\end{array}$ & $\begin{array}{l}\text { Multiple } \\
\text { Regression }\end{array}$ & ROA, ROE, ROCE & $\begin{array}{l}\text { They concluded that the banks in Kuwait have } \\
\text { been able to overcome the crisis primarily and } \\
\text { draws attention to the National Bank of Kuwait } \\
\text { was able to distribute profits at that stage }\end{array}$ \\
\hline 5 & $\begin{array}{l}\text { Almumani, } \\
\text { Mohammad } \\
\text { Abdelkarim } \\
\text { (2014a) }\end{array}$ & $\begin{array}{l}\text { A study on analyzing and } \\
\text { compare the Performance } \\
\text { of Saudi banks that listed } \\
\text { in stocks market for the } \\
\text { period } 2007-2011\end{array}$ & $2007-2011$ & $\begin{array}{l}\text { Trend analysis } \\
\text { and inter-firm } \\
\text { analysis }\end{array}$ & Financial Ratios & $\begin{array}{l}\text { It was found that increasing assets, operating } \\
\text { expenses, and cost to income decreased bank } \\
\text { profitability. In contrast, increasing operating } \\
\text { income causes an increase in profitability. The } \\
\text { analysis shows that all the study variables have a } \\
\text { positive mean value, and all banks generate } \\
\text { income. Joint venture banks proved to be more } \\
\text { proficient in generating profits, absorbing loan } \\
\text { losses, and dominating ROE. At the same time, } \\
\text { Saudi established banks have more capacity of } \\
\text { absorbing asset losses and dominating in ROA. }\end{array}$ \\
\hline
\end{tabular}




\begin{tabular}{|l|l|l|l|l|l|l|}
\hline S/N & Study & Purpose & $\begin{array}{l}\text { Year } \\
\text { Covered }\end{array}$ & $\begin{array}{l}\text { Estimation } \\
\text { Method }\end{array}$ & Variable & Summary of Findings \\
\hline 6 & $\begin{array}{l}\text { Gudata } \\
\text { Abara } \\
(2015)^{19}\end{array}$ & $\begin{array}{l}\text { Research on "financial } \\
\text { performance of five } \\
\text { commercial banks of the } \\
\text { period from 2007 to } 2011\end{array}$ & $\begin{array}{l}2007- \\
2011\end{array}$ & $\begin{array}{l}\text { T-test and } \\
\text { Ratio }\end{array}$ & $\begin{array}{l}\text { Liquidity, Solvency } \\
\text { and Risk } \\
\text { Management of } \\
\text { Banks }\end{array}$ & $\begin{array}{l}\text { The analysis was found that the Commercial } \\
\text { Bank of Ethiopia stands first in assets } \\
\text { management. In contrast, Awash International } \\
\text { Bank took the first rank in terms of profitability } \\
\text { performance. The Co-operative Bank pertains to } \\
\text { stand last in liquidity management. United Bank } \\
\text { stood at the first rank in solvency and risk } \\
\text { management among all sample banks under } \\
\text { study. }\end{array}$ \\
& $\begin{array}{l}\text { Ahsan, M. } \\
\text { K., (2013a) }\end{array}$ & $\begin{array}{l}\text { Analyze the financial } \\
\text { performance of three } \\
\text { selected Islamic Banks }\end{array}$ & $2007-2014$ & $\begin{array}{l}\text { CAMEL Rating } \\
\text { Analysis } \\
\text { approach }\end{array}$ & $\begin{array}{l}\text { CAR, AQ, MQ, EC } \\
\text { and Liquidty }\end{array}$ & $\begin{array}{l}\text { The study found that all the selected Islamic } \\
\text { Banks are firmly positioned on their composite } \\
\text { rating system. They are sound in every respect, } \\
\text { i.e., sound in capital adequacy, asset quality, } \\
\text { management quality, earning capacity, and } \\
\text { liquidity conditions. }\end{array}$ \\
\hline 7 & & & & &
\end{tabular}

Table 2. Horizontal Analysis of Income Statement and Statement of Comprehensive Income for the Period from $2008-2017$

\begin{tabular}{|c|c|c|c|c|c|c|c|c|c|c|}
\hline & 2008 & 2009 & 2010 & 2011 & 2012 & 2013 & 2014 & 2015 & 2016 & 2017 \\
\hline TOI & $(9.43 \%)$ & $0.32 \%$ & $6.80 \%$ & $13.43 \%$ & $33.23 \%$ & $35.13 \%$ & $45.66 \%$ & $45.06 \%$ & $44.79 \%$ & $81.20 \%$ \\
\hline NOI & $(49.81 \%)$ & $5.58 \%$ & $37.55 \%$ & $46.08 \%$ & $71.59 \%$ & $92.15 \%$ & $107.12 \%$ & $107.69 \%$ & $195.88 \%$ & $157.65 \%$ \\
\hline OP & $(76.81 \%)$ & $(16.24 \%)$ & $1.14 \%$ & $24.65 \%$ & $30.31 \%$ & $52.46 \%$ & $67.80 \%$ & $56.24 \%$ & $60.61 \%$ & $88.49 \%$ \\
\hline PBT & $(78.68 \%)$ & $(12.56 \%)$ & $3.22 \%$ & $20.04 \%$ & $33.44 \%$ & $45.32 \%$ & $60.32 \%$ & $51.38 \%$ & $53.99 \%$ & $84.37 \%$ \\
\hline PFY & $(80.99 \%)$ & $(13.23 \%)$ & $5.52 \%$ & $31.59 \%$ & $36.23 \%$ & $45.89 \%$ & $58.72 \%$ & $73.83 \%$ & $256.09 \%$ & $101.28 \%$ \\
\hline $\mathrm{TCl}$ & NA & NA & $(8.73 \%)$ & $16.24 \%$ & $42.03 \%$ & $(10.52 \%)$ & $23.44 \%$ & $19.01 \%$ & $130.95 \%$ & $46.87 \%$ \\
\hline PAEP & NA & $\mathrm{NA}$ & $(9.38 \%)$ & $16.35 \%$ & $40.10 \%$ & $(10.73 \%)$ & $21.83 \%$ & $18.11 \%$ & $132.02 \%$ & $45.30 \%$ \\
\hline $\mathrm{NCl}$ & NA & NA & $30.89 \%$ & $9.42 \%$ & $160.47 \%$ & $4.45 \%$ & $121.73 \%$ & $74.08 \%$ & $65.18 \%$ & $142.93 \%$ \\
\hline
\end{tabular}

Source: Computed Value from Annual Reports of Bank of China - TOI - Total Operating Income; NOI - Net Operating Income; OP - Operating Profit; PBT - Profit before Tax; PFY -

Profit for the Year; TCI - Total Comprehensive Income; PAEP - Profits Attributable to Equity Participants; NCI - Non-Controlling Interest; NA - Not applicable. 
Table 3. Vertical Analysis of Income Statement and Statement of Comprehensive Income for the Period from 2008 -2017

\begin{tabular}{|c|c|c|c|c|c|c|c|c|c|c|}
\hline & 2008 & 2009 & 2010 & 2011 & 2012 & 2013 & 2014 & 2015 & 2016 & 2017 \\
\hline NOI & $\begin{array}{c}12,953 \\
(100 \%) \\
\end{array}$ & $\begin{array}{l}27,245 \\
(100 \%) \\
\end{array}$ & $\begin{array}{l}27,823 \\
(100 \%) \\
\end{array}$ & $\begin{array}{l}40,340 \\
(100 \%) \\
\end{array}$ & $\begin{array}{l}34,901 \\
(100 \%) \\
\end{array}$ & $\begin{array}{l}39,576 \\
(100 \%)\end{array}$ & $\begin{array}{l}43,232 \\
(100 \%) \\
\end{array}$ & $\begin{array}{l}40,011 \\
(100 \%) \\
\end{array}$ & $\begin{array}{l}41,176 \\
(100 \%) \\
\end{array}$ & $\begin{array}{l}47,693 \\
(100 \%) \\
\end{array}$ \\
\hline OE & $\begin{array}{c}8,771 \\
(67.71 \%)\end{array}$ & $\begin{array}{c}12,141 \\
(44.56 \%)\end{array}$ & $\begin{array}{c}9,584 \\
(34.45 \%)\end{array}$ & $\begin{array}{c}7,862 \\
(19.49 \%)\end{array}$ & $\begin{array}{c}11,402 \\
(32.67 \%)\end{array}$ & $\begin{array}{c}12,083 \\
(30.53 \%)\end{array}$ & $\begin{array}{c}12,972 \\
(30.01 \%)\end{array}$ & $\begin{array}{c}11,836 \\
(29.58 \%)\end{array}$ & $\begin{array}{c}12,213 \\
(29.66 \%)\end{array}$ & $\begin{array}{c}13,703 \\
(28.73 \%)\end{array}$ \\
\hline OP & $\begin{array}{c}4,182 \\
(32.29 \%)\end{array}$ & $\begin{array}{c}15,104 \\
(55.44 \%)\end{array}$ & $\begin{array}{c}18,239 \\
(65.55 \%)\end{array}$ & $\begin{array}{c}22,478 \\
(55.72 \%)\end{array}$ & $\begin{array}{c}23,499 \\
(67.33 \%)\end{array}$ & $\begin{array}{c}27,493 \\
(69.47 \%)\end{array}$ & $\begin{array}{c}30,260 \\
(69.99 \%)\end{array}$ & $\begin{array}{c}28,175 \\
(70.42 \%)\end{array}$ & $\begin{array}{c}28,963 \\
(70.34 \%)\end{array}$ & $\begin{array}{c}33,990 \\
(71.27 \%)\end{array}$ \\
\hline PBT & $\begin{array}{c}4,078 \\
(31.48 \%)\end{array}$ & $\begin{array}{c}16,724 \\
(61.38 \%) \\
\end{array}$ & $\begin{array}{c}19,742 \\
(70.96 \%)\end{array}$ & $\begin{array}{c}24,680 \\
(61.18 \%) \\
\end{array}$ & $\begin{array}{c}25,521 \\
(73.12 \%) \\
\end{array}$ & $\begin{array}{c}27,793 \\
(70.23 \%)\end{array}$ & $\begin{array}{c}30,663 \\
(70.93 \%) \\
\end{array}$ & $\begin{array}{c}28,952 \\
(72.36 \%)\end{array}$ & $\begin{array}{c}29,452 \\
(71.53 \%)\end{array}$ & $\begin{array}{c}35,262 \\
(73.93 \%)\end{array}$ \\
\hline PFY & $\begin{array}{c}3,007 \\
(23.21 \%)\end{array}$ & $\begin{array}{c}14,046 \\
(51.55 \%)\end{array}$ & $\begin{array}{c}16,690 \\
(59.99 \%)\end{array}$ & $\begin{array}{c}20,813 \\
(51.59 \%)\end{array}$ & $\begin{array}{c}21,547 \\
(61.74 \%)\end{array}$ & $\begin{array}{c}23,075 \\
(58.31 \%)\end{array}$ & $\begin{array}{c}25,105 \\
(58.07 \%)\end{array}$ & $\begin{array}{c}27,495 \\
(68.72 \%)\end{array}$ & $\begin{array}{c}56,323 \\
(136.79 \%)\end{array}$ & $\begin{array}{c}31,837 \\
(66.75 \%)\end{array}$ \\
\hline $\mathrm{TCl}$ & NA & $\begin{array}{c}23,578 \\
(86.54 \%)\end{array}$ & $\begin{array}{c}21,758 \\
(78.20 \%)\end{array}$ & $\begin{array}{c}27,711 \\
(68.69 \%)\end{array}$ & $\begin{array}{c}33,860 \\
(97.02 \%)\end{array}$ & $\begin{array}{c}21,332 \\
(53.90 \%)\end{array}$ & $\begin{array}{c}29,427 \\
(68.07 \%)\end{array}$ & $\begin{array}{c}28,371 \\
(70.91 \%) \\
\end{array}$ & $\begin{array}{c}55,058 \\
(133.71 \%)\end{array}$ & $\begin{array}{c}35,013 \\
(73.41 \%)\end{array}$ \\
\hline PAEP & $\begin{array}{c}3,343 \\
(25.81 \%) \\
\end{array}$ & $\begin{array}{c}23,196 \\
(85.14 \%)\end{array}$ & $\begin{array}{c}21,258 \\
(78.40 \%)\end{array}$ & $\begin{array}{c}27,293 \\
(67.66 \%)\end{array}$ & $\begin{array}{c}32,865 \\
(94.17 \%) \\
\end{array}$ & $\begin{array}{c}20,933 \\
(52.89 \%)\end{array}$ & $\begin{array}{c}28,580 \\
(66.11 \%)\end{array}$ & $\begin{array}{c}27,706 \\
(69.25 \%)\end{array}$ & $\begin{array}{c}54,427 \\
(132.18 \%)\end{array}$ & $\begin{array}{c}34,085 \\
(71.47 \%)\end{array}$ \\
\hline $\mathrm{NCl}$ & $\begin{array}{c}(336) \\
(2.59 \%)\end{array}$ & $\begin{array}{c}382 \\
(1.40 \%)\end{array}$ & $\begin{array}{c}500 \\
(1.80 \%)\end{array}$ & $\begin{array}{c}418 \\
(1.04 \%)\end{array}$ & $\begin{array}{c}995 \\
(2.85 \%)\end{array}$ & $\begin{array}{c}399 \\
(1.01 \%)\end{array}$ & $\begin{array}{c}847 \\
(1.96 \%)\end{array}$ & $\begin{array}{c}665 \\
(1.66 \%)\end{array}$ & $\begin{array}{c}631 \\
(1.53 \%)\end{array}$ & $\begin{array}{c}928 \\
(1.95 \%)\end{array}$ \\
\hline
\end{tabular}

Source: Computed Value from Annual Reports of Bank of China - NOl- Net Operating Income after impairment loss; OE - Operating Expenses; OP - Operating Profit; PBT - Profit before Tax; PFY - Profit for the year; TCI - Total Comprehensive Income; PAEP - Profits attributable to Equity Participants; NCl - Non-Controlling Interest 
Table 4. Ratio Analysis: Measurement of Financial Statement for the period from 2008 -2017

\begin{tabular}{|c|c|c|c|c|c|c|c|c|c|c|c|c|c|}
\hline & 2008 & 2009 & 2010 & 2011 & 2012 & 2013 & 2014 & 2015 & 2016 & 2017 & Mean & S.D. & C.V (\%) \\
\hline \multicolumn{14}{|c|}{ (i) Profitability Ratios } \\
\hline OPM & $16.38 \%$ & $57.97 \%$ & $66.30 \%$ & $72.87 \%$ & $65.71 \%$ & $68.20 \%$ & $68.33 \%$ & $68.82 \%$ & $69.37 \%$ & $69.70 \%$ & 62.37 & 3.52 & 0.06 \\
\hline ROA & $0.27 \%$ & $1.19 \%$ & $1.21 \%$ & $1.14 \%$ & $1.24 \%$ & $1.22 \%$ & $1.19 \%$ & $1.07 \%$ & $2.38 \%$ & $1.14 \%$ & 1.21 & 0.78 & 0.64 \\
\hline ROE & $4.04 \%$ & $13.34 \%$ & $14.06 \%$ & $15.74 \%$ & $13.86 \%$ & $14.01 \%$ & $13.91 \%$ & $13.91 \%$ & $24.71 \%$ & $12.80 \%$ & 10.91 & 1.44 & 0.13 \\
\hline ROC & $4.95 \%$ & $14.30 \%$ & $15.42 \%$ & $16.88 \%$ & $15.15 \%$ & $16.87 \%$ & $16.67 \%$ & $14.23 \%$ & $12.56 \%$ & $13.74 \%$ & 14.08 & 0.75 & 0.05 \\
\hline $\mathrm{Cl}$ & $34.36 \%$ & $46.60 \%$ & $34.84 \%$ & $25.49 \%$ & $31.88 \%$ & $29.97 \%$ & $29.29 \%$ & $28.91 \%$ & $29.25 \%$ & $28.10 \%$ & 31.87 & 1.25 & 0.04 \\
\hline \multicolumn{14}{|c|}{ (ii) Solvency Ratios } \\
\hline D/TA & 0.78 & 0.77 & 0.81 & 0.80 & 0.76 & 0.76 & 0.77 & 0.84 & 0.71 & 0.71 & 0.77 & 8.63 & 11.20 \\
\hline$D / E$ & 12.57 & 10.48 & 13.04 & 12.05 & 10.81 & 11.56 & 11.06 & 10.96 & 9.10 & 9.70 & 11.13 & 2.39 & 0.21 \\
\hline $\mathrm{D} / \mathrm{C}$ & 0.914 & 0.900 & 0.920 & 0.56 & 0.90 & 0.91 & 0.90 & 0.90 & 0.88 & 0.88 & 0.87 & 0.23 & 0.26 \\
\hline ATR & $2.22 \%$ & $2.15 \%$ & $1.66 \%$ & $1.77 \%$ & $1.95 \%$ & $1.97 \%$ & $2.02 \%$ & $1.73 \%$ & $1.79 \%$ & $1.84 \%$ & 1.91 & 3.90 & 2.04 \\
\hline L/D & $56.74 \%$ & $60.98 \%$ & $59.69 \%$ & $61.00 \%$ & $63.32 \%$ & $64.63 \%$ & $64.79 \%$ & $63.25 \%$ & $64.55 \%$ & $64.50 \%$ & 62.35 & 5.68 & 0.09 \\
\hline CAR & $16.17 \%$ & $16.85 \%$ & $16.14 \%$ & $16.90 \%$ & $16.80 \%$ & $15.80 \%$ & $17.51 \%$ & $17.86 \%$ & $22.35 \%$ & $20.39 \%$ & 17.68 & 4.44 & 0.25 \\
\hline \multicolumn{14}{|c|}{ (iii) Investment Ratios } \\
\hline $\mathrm{P} / \mathrm{E}$ & 27.77 & 13.56 & 17.27 & 9.52 & 12.17 & 11.81 & 11.16 & 9.29 & 11.94 & 14.70 & 13.92 & 11.42 & 0.82 \\
\hline EPS & 0.3162 & 1.2981 & 1.5319 & 1.9323 & 1.9796 & 2.1046 & 2.3246 & 2.5520 & 2.3243 & 2.6938 & 1.91 & 1.49 & 0.78 \\
\hline DPS & 0.438 & 0.855 & 0.972 & 1.188 & 1.238 & 1.010 & 1.120 & 1.224 & 1.880 & 1.398 & 1.13 & 0.79 & 0.70 \\
\hline
\end{tabular}

作 Cl - Cost to Income; D/TA -Debt to Total Asset; D/E - Debt to Equity; D/C - Debt to Capital; ATR - Asset Turnover; L/D - Loan to Deposit; CAR - Capital Adequacy Ratio; P/E - P/E Ratio in (HK \$); EPS - Earnings Per Share (HK \$); DPS - Dividend Per Share (HK. \$) 


\section{METHODOLOGY}

\subsection{Data Sources}

The present study utilized the quantitative research methodology. To examine the measuring financial performance, the accounting information was derived from published and audited annual reports of the Bank of China (Hong Kong) group for ten consecutive periods from 2008 to 2017. In addition to realizing the study's objectives, documents from various sources, websites, and departmental manual and literature records have been reviewed.

\subsection{Method of Data Analysis}

The collected data were measured using both descriptive and inferential statistical tools like percentage, mean, standard deviation, and variation coefficient. Several methods that can be used to measure financial statements are also termed financial analysis techniques or tools. Out of these, horizontal, vertical, and ratio can choose those suitable techniques to its requirements to the present study. Gitman (2004) says that financial analysis's principal techniques are comparative statements, common-size statements, trend analysis, cash flow analysis, and ratio analysis.

\section{ANALYSIS \& DISCUSSION}

\subsection{Measurement of Financial Statement: Horizontal Analysis}

Horizontal analysis compares historical data, such as ratios, or line items, over several accounting periods. Jawarhar Lal (2003b) mentioned that "the percentage analysis of increases and decreases in corresponding items in comparative financial statements is called the horizontal analysis." Under this analysis, the current year's figures are compared with the base year, and changes are usually shown in percentages. This analysis is also called dynamic analysis, which helps the management gain insight into levels and areas of strength and weaknesses.

Table 2 shows that the horizontal analysis and its growth rate of the BOCs \% of total operating income have grown over the study period except 2008 (9.43\%) and 2009 $(0.32 \%)$ due to the extreme volatilities in major financial markets, particularly in the second half of the year, triggered by the collapse of Lehman brothers. In 2017, BOC reached $81.20 \%$ of the total operating income, the highest in the above study periods. The impact of the global financial turmoil; the Group's traditional banking business continued to deliver solid performance; its investment-related businesses were negatively affected by the financial crisis's fallout. A slight decline $(0.27 \%)$ in total operating income from $45.06 \%$ in 2015 to $44.79 \%$ in 2016 due to the global economy once again fell into a deep correction and struggled to recover, giving rise to some risks and challenges.

Against a backdrop of shrinking international trade, extreme movements in commodity prices, and frequent swings in financial markets, economies across the world continued to be mired in the most prolonged and weakest recovery cycle since the great depression of the last century except developed countries. The net operating income is dramatically increased throughout the study period from 2008 until 2017 and $195.88 \%$ highest in 2016. (76.81\%) in 2008 and (16.24\%) in 2009, operating profit has negatively increased due to the weak market demand and pressure from low-interest rates. 
The BOC group reported a mild increase in net operating income before impairment allowances to $\mathrm{HK} \$ 26,055$ million. Operating profit before impairment allowances declined by $17.0 \%$ to $\mathrm{HK} \$ 13,914$ million due to the expenses mainly concerning the Lehman minibonds issue. The operating profit reflects $88.49 \%$ highest in the year 2017 . Before taxation, the profit dramatically increased over the study period, especially $84.37 \%$ and $60.32 \%$ in 2017 and 2014, respectively, except in 2008 and 2015 due to the reasons mentioned earlier. The year's profit just wriggled at the beginning of the study periods 2008 and 2009 afterwards has increased continuously with highest in 2016 (256.09\%). Total comprehensive income struggled with the beginning of the study period, and $2010(8.73 \%)$ and $2013(10.52 \%)$ has a negative figure, and $130.95 \%$ in 2016 earned the highest \% of its overall income banking activities. The percentage of profits attributable to the equity participants also similar negative trends, like comprehensive income $9.38 \%$ \& $10.73 \%$ in 2010 and 2013 and the highest $132.02 \%$ available to distribute to equity shareholders in 2016. The above analysis concluded that the percentage growth rate of financial Performance of BOC has dramatically increased except 2008, 2009, 2013, 2015, and 2017 due to the variables like extreme volatilities in major financial markets, weak external trade, steady economic development in the mainland of China and the global economy fell into a deep correction and struggle to recover.

\subsection{Measurement of Financial Statement: Vertical Analysis}

Vertical analysis or common-size analysis is a method of analysis. Each line item is listed as a percentage of a base figure within the statement. Jawarharlal (2003b) says that "vertical analysis uses percentages to show the different parts' relationship to the total in a single statement." The vertical analysis approach highlights the structure of financial position statements by presenting non-current assets, working capital, debt, and equity as a percentage of debt plus equity, according to Elliott and Elliott (2017).

From Table 3, we understand that the bank's performance using vertical analysis of the BOC's group net operating income (NOI) after impairment allowances is 12,953 million HK\$ in 2008 (before impairment loss 25,256 million HK\$) which is a 7.33\% decreased from the previous year. It has increased continuously over the study period. Highest 47,693 million HK\$ in 2017 due to the country's stable social and economic development and a slight reduction in 2015 due to the global economy again fell into a deep struggled to recover, a backdrop of shrinking international trade, extreme movements in commodity prices, and frequent swings in financial markets, economies across the world continued to be mired in the most prolonged and weakest recovery cycle since the great depression of the last century. So, the BOC has taken several risks and challenges to face above mentioned reasons.

BOC has efficiently controlled the operating expenses (OE) throughout the study period and $67.71 \%$ highest in 2008 due to the Lehman brothers' mini-bonds issue, uncertainties arising from mounting inflationary pressures in the emerging market debt crisis in Europe. The operating expenses decreased to HK\$7,862 (19.49\%) in 2011 compared to $2010 \mathrm{HK} \$$ 9,584 (34.45\%) due to its efficient stewardship. The Group's amount of profits for the year (PFY) has increased continuously over the study period and 3,007 HK\$ (23.21\%) lowest in 2008 and 56,323 HK\$ (136.79\%) highest amount in 2016. Total comprehensive income (TCl) of the Group increased progressively except the in $2013(12,528$ HK\$ (43.12\%) declined) due to weak external trade, steady economic development in the mainland of China, and resilient local labour market created conditions for a robust expansion of private consumption to be the driver of GDP growth in Hong Kong. So, the operating 
environment for the banking sector remained challenges. The vertical growth rate concluded that BOCs growth percentage is proportionately increased except 2008, 2013, 2016, and 2017 due to abnormal factors of internal and external factors.

\subsection{Measurement of Financial Performance: Ratio Analysis}

According to Goel (2016), the financial ratios are classified according to the analysis's objective. The ratios are profitability ratios, efficiency ratios, liquidity ratios, solvency ratios, and market ratios. Bucci (2014) pointed out that profitability ratios are ways a firm looks at its profits compared to its sales, assets, and ownership. It can see whether it is making a good profit compared to these other financial numbers. These are the significant ratios viewed by banks, lenders, and investors for analysis purposes.

From Table 4, we could clearly understand that the BOCs profitability, solvency, and related financial ratio have been explained in brief. Profitability is a measure of net earnings relative to components used to generate earnings by Tulsian (2014). Measuring profitability is essential for gauging a company's quality and providing a basis for valuation as an enterprise or investment. Investors are mainly concerned with profitability measures. BOCs operating profit margin (OPM) has increased progressively, especially highest in 2011 (72.87\%) and lowest growth rate in 2008 (16.38\%). In 2011, the Group's net operating income before impairment allowances was HK\$30,846 million, up $12.1 \%$ yearon-year. Operating profit before impairment allowances was HK\$22,984 million, up 28.2\% year-on-year. If the net recovery and the Lehman Brothers related expenses were to be excluded, the Group's profit attributable to the equity holders would still have increased by $11.5 \%$.

Due to the weak market demand and pressure from low interest rates, the Group reported a mild increase in net operating income before impairment allowances to HK\$26,055 million in 2008. Operating profit before impairment allowances declined by $17.0 \%$ to HK\$13,914 million due to the Lehman mini-bonds issue's expenses. If excluding the related expenses, operating profit before impairment allowances would be down modestly by $1.9 \%$. The average of the operating profit from the above study periods also is good $62.37 \%$, which seems relatively consistent as the standard deviation being only 3.52 .

Return on Assets (ROA) measure of efficiency, providing evidence for how well a company utilizes assets or equity to generate revenue and profit. BOCs ROA and its \% growth rate were average over the study period from 2008 to 2017. $0.27 \%$ growth in 2008 and before impairment allowances was $1.52 \%$ and $2.38 \%$ highest return on through assets growth in 2016; total assets amounted to HK\$2,327,781 million, edging down $2.3 \%$ compared with the end of 2015 and filling the gap in total assets from the disposal of NCB. ROA and its mean and standard deviation value for the above study period are 1.21 and 0.78 , respectively.

Return on equity (ROE) may also be classified as an investment ratio since; investors can use it to assess the desirability of a company's ordinary shares. BOCs return on average shareholders' fund has grown steadily by $4.04 \%, 13.34 \%, 14.06 \%$ and $15.74 \%$ over the study period from 2008 to 2011 and reached the highest percentage, $24.71 \%$ in 2016 . The mean value of ROE from the above study periods is 10.91 , which seems to be relatively consistent with the standard being only 1.44. The return on equity is higher than current savings rates; this might indicate that its ordinary shares are a good investment. 
Whiting (1986) says that the return on capital employed (ROCE) is regarded by most businesses (except tiny ones) as their key measure of total performance. ROCE measures a company's profitability by expressing its operating profit as a percentage of its capital employed. BOC's return on capital employed (ROCE) has increased gradually over the study period, which constitutes the lowest $4.95 \%$ in 2008 due to low profits and $16.88 \%$ highest in 2011, indicating that the BOC generates more earnings per dollar of capital employed. The average mean value of ROCE is 14.08 and its standard deviation 0.75 . BOC has efficiently controlled cost throughout the study period from 2008 to 2017. Delen \& Kuzey $(2013)^{27}$ argue that interest, tax greatly influence EBIT, so the company uses EBIT to measure how it controls operating expenses and costs. From the analysis, $46.60 \%$, which constituted high costs in 2009 and followed by the lowest $25.49 \%$ in 2011 whereas BOC's remaining periods stable the cost-effectively. The profitability ratios could understand that BOC variation's co-efficiency is small and indicates fewer variables and more stable or more uniform to the investors.

Solvency ratios show that how efficiently a company can use its net assets to generate revenue. Fairfield and Yohn (2001) pointed out that the net asset turnover ratio is an essential financial ratio to measure company asset management's efficiency. It is usually used to analyze the turnover rate of company assets. Some economists think that the faster its turnovers, the more substantial company's selling power. BOC has a stable growth rate of debt on total assets over the study period except in 2010. Due to asset quality, it further improved with a classified or impaired loan ratio of 0.10 . The BOC's Group's total asset grew 37\% HK\$1,661 billion, driven by core growth and rapid expansion of local RMB business in the Hong Kong environment. The mean value of debt to total nets assets is 0.77 , and its standard deviation and co-efficiency of variance value represent 8.63 and 11.20 .

Debt to equity or leverage ratio measures the degree to which the $\mathrm{BOC}$ assets are financed by the debts and the shareholders' equity of a business. BOC's lower values of debt-to-equity ratio $10.96 \%$ in $2015,9.10 \%$ in 2016 , and $9.70 \%$ in 2017 are favourable, indicating less risk. The higher debt-to-equity ratio is unfavourable because it means that the BOC relies more on external lenders; thus, it is at higher risk, especially at higher interest rates in $13.04 \%$ in 2010, 12.05\% in 2011, and $12.57 \%$ in 2008 due to impact on environmental factors. An increasing trend in the debt-to-equity ratio is also alarming because it means that the percentage of assets of a business financed by debts is increasing. Thus, BOCs risk level has been reducing from 2013 onwards, which means low-risk level. Based on the above computation, the mean value 11.13, standard deviation, and co-efficiency of variation constitutes 2.39 and 0.21 , respectively.

The debt to capital ratio measures the proportion of the sum of interest-bearing debt and shareholders' equity. The higher debt included in the capital employed means a higher risk of insolvency. Based on the above computation, BOC has maintained a stable growth rate of debt against capital employed. It concluded that the business maintains a lower risk of insolvency, and 0.83 resulted in average value, the standard deviation of 0.23 , and a co-efficiency of variation $(0.26$.

BOC's Asset turnover ratio shows that the sales to its assets show how successfully the assets are employed to generate revenue. BOC generates more sales with fewer assets from $2010(1.66 \%)$ until $2014(2.02 \%)$ has a higher turnover ratio, which tells it is a good company because it uses its assets efficiently in an effective way. BOC turnover ratio declined in 2015 (1.73\%), 2016 (1.79\%), and 2017 (1.84\%) due to not using its assets 
optimally due to internal environmental operating factors. BOC's consolidated capital adequacy ratio stood comfortably at $16.17 \%$ as of the end of 2008 . Also, BOC continued to exercise rigorous risk control and focus on liquidity management throughout the study period. Banking regulators require a minimum capital adequacy ratio to provide the banks with a cushion to absorb losses before becoming insolvent. This improves stability in financial markets and protects deposit-holders. BOC's solvency ratio and its coefficient of variation are minor except for the debt to total asset ratio $(11.20 \%)$ and asset turnover ratio (2.04). It indicates that there are fewer variables and more stable or more uniform to the investors.

The BOC group's profit attributable to shareholders has mainly decreased due to the Group's securities investments' continued markdowns. Earnings per share of BOC have increased gradually over the above study periods. In 2009, the Group's profit attributable to shareholders increased by $310.6 \%$ year on year to $\mathrm{HK} \$ 13,725$ million or $\mathrm{HK} \$ 1.2981$ per share. BOC has declared earnings per share HK\$1.5319, HK\$1.9323, HK\$1.9796, HK\$ 2.1046 in 2010, 2011, 2012, and 2013 respectively to its shareholders. HK\$2.6938 per share was declared the highest in the year 2017.

\section{FINDINGS AND CONCLUSION}

The present study examines BOC's financial performance measurement measured through horizontal, vertical, and ratio analysis over the study periods from 2008 to 2017. From the above analysis, the horizontal and vertical analysis of $\mathrm{BOC}$ has a variable growth rate of percentage and amount of $\mathrm{HK} \$$ due to external and internal operating environmental factors. Hence, based on Hypothesis $\mathrm{H} 1$, the study clearly shows that the method of financial statement analysis associated with measuring the BOC's financial performance and its competency over the study period is a reasonable growth rate except for few years.

As for this paper's results, strong evidence suggests that commercial banks are relatively less profitable and less liquid and are exposed to risk compared to the banking industry. Concerning credit performance of this study finds no unambiguous conclusion by Khan Samad (2004b). Based on hypothesis H2, it could be concluded that BOC's operating efficiency and overall measurement of bank's financial performance in terms of profitability and solvency declined due to internal and external operating environments during the years 2008, 2009, 2013, and 2015. Moreover, in 2008 (Lehman Brothers Mini-Bond Issue), the external environmental factors were a highly challenging year with an unusual combination of complicated events the bank faced and the extreme volatilities in major financial markets, particularly the second half of the same year. Shareholders of BOC did not receive satisfying dividends of their investment mainly in 2008 due to environmental factors.

To better understand financial performance, the archival literature shows that important papers have proved that profitability is an increasing capital and loan ratio function. Besides, the study highlights the empirical role that adequate capital ratios and loan portfolios play in explaining the Performance of Islamic banks stated by Bashir (1999a). $\mathrm{BOC}$ has an uncertain economic environment and a challenging year for the entire banking industry. However, the opportunities captured were more significant than ever in 2009. Despite the internal environmental operating factors like weak market demand and pressure from low-interest rate, the Group reported a mild increase in net operating profit before impairment allowances. Due to the global financial 2008 and the debt crisis in 
Europe 2011, Hong Kong's operating environment was characterized by a sluggish global economy, stringent regulatory requirements. Persistently low-interest rates affected the profits of the BOC in 2012.

Thus, consistent with prior literature, this paper's review results also support the positive relationship between different scholars trying to use various financial ratios as a proxy to measure management efficiency. The earning quality mainly measures the profitability and productivity of the bank. It explains the growth and sustainability of future earnings capacity, concluded by Ahsan (2013b). The weak internal trade and steady economic development in mainland China and the resilient local labour market created conditions for a robust expansion of private consumption to drive GDP growth in Hong Kong. The BOC's operating environment was affected in 2013 even though the BOC has continued volatiles global financial markets, particularly in the last quarter of the year 2014, and experienced plummeting oil prices in the same year.

Based on hypothesis $\mathrm{H} 3$, ratio analysis shows a significant statistical relationship between BOC's strengths and weaknesses. The financial performance of Saudi banks is studied based on financial ratios and variables. Financial performance was measured by two approaches; trend analysis and inter-firm analysis. An investigation found increasing assets, operating expenses, and cost to income because of decreased bank profitability. In contrast, increasing operating income causes an increase in banks' profitability. The analysis shows that all the study variables have a positive mean value, and all banks generate income. Saudi joint venture banks proved to be more proficient in generating profits, absorbing loan losses, and dominating ROE. At the same time, Saudi established banks have more capacity of absorbing asset losses and dominating in ROA in the study of Almumani (2014b).

Additionally, the US was set to normalize its monetary policy. Simultaneously, weakened economic momentum in Europe and Japan prompted further quantitative easing measures in the same year. This, coupled with plummeting oil prices, heightened market anxiety. Hence, BOC's profitability ratios could be inferred clearly about operating profit, return on asset, return on equity, and return on capital employed. Its coefficient of variation is small. It indicates that there are fewer variables and more stable or more uniform to the investors.

Moreover, the global economy once again fell into a deep correction and struggled to recover, giving rise to several risks and challenges during 2015, significantly shrinking international trade, extreme movements in commodity prices, and frequent swings in financial markets, economies across the world continued to be mired in the most prolonged and weakest recover cycle since the great depression of the last century. Amid this complexity in the external environment, Hong Kong, as an open economy, recorded poor foreign trade results. Return on capital employed just has decreased from the above analysis. Again, the global economy fell into deep sluggish to recover and a backdrop of shrinking international trade, extreme movements in commodity prices, and frequent swings in financial markets in 2016. The developed countries' low growth trajectory continued, as did the moderating growth trend in developing countries. Despite such a complicated operating environment, BOC was able to rise to these challenges. BOC's solvency ratio and its coefficient of variation are small except for the Debt to Total Asset Ratio (11.20\%) and Asset Turnover Ratio (2.04). It indicates that there are fewer variables and more stable or more uniform to the investors. The ratio analysis and its measurement 
Jeyaraj, S. S. \& Sumathi, M.

are favourable to the existing and prospective investors, increasing the investors' confidence level.

Hence, the present study is crucial to measure the bank's profitability, solvency, operating, and other indicators that the business conducted in a rational and normal way, ensuring enough returns to the shareholders to maintain its market value progressively. Finally, the BOC's board of directors seriously considers the periods mentioned above. It has been taking remedial measures to recover /improve financial performance in operating, profitability, and solvency of banks from such areas, which would benefit the investors and help make financial decisions.

\section{REFERENCES}

Ahsan, M. K. (2013) Measuring Financial Performance Based on CAMEL: A Study on Selected Islamic Banks in Bangladesh, Asian Business Review, 6(1), 2305-8730.

Almumani, Mohammad Abdelkarim (2014). A Study on Analyze and Comparison of Financial Performance of Saudi Banks (2007-2011), Asian Journal of Research in Banking and Finance, 4(2), 200-213.

Alsamaree, Adnan Hashim (2013) Financial Ratios and the Performance of Banks, Journal of Research in International Business and Management, 3(1), 17-19.

Altan, M., Beduk, A., \& Yusufazari, H., (2014). Performance Analysis of Banks in Turkey Using Camel Approach, $14^{\text {th }}$ International Academic Conference, Malta

Bashir, A.H. M., (1999). Risk and Profitability Measures in Islamic Banks: The Case of Two Sudanese Banks, Islamic Economic Studies 6, 1-24.

Beaver, W.H., (2002). Perspectives on Recent Capital Market Research, The Accounting Review, 77(2), 453474.

Bikker, J. A. (2010). Measuring performance of banks: an assessment. Retrieved from https://www.dnb.nl/binaries/JABE\%20Measuring\%20performance\%20of\%20 banks_tcm46237545.pdf

Bucci, R. (2014). Medicine and Business, Financial Ratios, International Publishing Springer: Switzerland. CSR Report of Bank of China (PDF) 2010, Retrieved September 12, 2011

Delen, D., Kuzey, C., \& Uyar, A. (2013). Measuring firm performance using financial ratios: A decision tree approach, Expert Systems with Applications, 40(10), 3970-3983.

Elliott Barry \& Elliott Jamie (2017). Structure of the Statement of Financial Position, Financial Accounting, Reporting, and Analysis, Edinburgh Gate, UK, Pearson Education Ltd.

Fairfield, P. M., \& Yohn, T. L., (2001). Using Asset Turnover and Profit Margin to Forecast Changes in Profitability, Review of Accounting Studies, 6(4), 371-385.

Funso, T. K. Kolasade, A.R. \& Ojo, O. M. (2012). Credit Risk and Commercial Banks' Performance in Nigeria: A Panel Model Approach, Australian Journal of Business and Management Research, 2(2), 31-38.

Gitman, L. J. (2004). Principles of Managerial Finance, S. I.: Pearson Education

Goel, S. (2016). Financial Ratios, Business Expert Press, $1^{\text {st }}$ Ed., New York:

Gudata, A. (2015). Financial Performance Analysis in Banking Sector: in Selected Commercial Banks in Ethiopia, International Journal of Current Research, 7(10) 21883-21886.

Jaiswal, A., \& Jain, C., (2016). A Comparative Study of Financial Performance of SBI and ICICI Banks in India, International Journal of Scientific Research in Computer Science and Engineering, 4(3), 2320-7639

Jawahar Lal, (2003). Relationship of the Financial Statements, Advanced Management Accounting: Text, Problems and Cases, New Delhi, S. Chand \& Publishing Company Ltd.

Metcalf, R. W., \& Titard, P. L. (1976). Relationships in the Financial Statements, Principles of Accounting, W. B. Saunders, (Philadelphia) 157

Khan M.Y, \& Jain P.K. (2007). Financial Management Text, Problems, and Cases, New Delhi, Tata McGrawHill Publishing Company Ltd.

Narayanaswamy, R. (2014). Financial Accounting: A Managerial Perspective, Delhi: PHI Learning

Rashid, M., (2010). Banking Sector Challenges in Bangladesh, The Daily Star

Rees, B. (1995). Financial Analysis", UK, Prentice-Hall International

Samad, K. (2004). Performance of Bahrain's commercial banks with respect to credit, liquidity and profitability performances during 1994-2001, Credit and Financial Management Review, 10(1), 33-40.

Singh, A. J \& Schmidgall, R.S., (2002). Analysis of Financial Ratios commonly used by the US. Lodging financial executives, Retain \& Leisure Property, 2(3), 201-213.

Srinivas, K., \& Saroja, L. (2013). Comparative financial performance of HDFC Bank and $\mathrm{ICICl}$ Bank. International Refereed Multidisciplinary Journal of Contemporary Research, 1(2), 108-126. 
Tulsian, M. (2014). Profitability Analysis (A comparative study of SAIL \& TATA Steel), IOSR Journal of Economics and Finance, 3(2), 19-22

Whiting, E., (1986). A Guide to Business Performance Measurements.Uk, Palgrave Macmillan

Yalcin, N, Bayrakdarogly, A, Kahraman, C., (2012). Application of fuzzy multi-criteria decision-making methods for financial performance evaluation of Turkish manufacturing industries, Expert Systems with Applications, 39(1), 350- 364. https://doi.org/10.1016/j.eswa.2011.07.024 